EA 4272

\title{
Chartering practices in liner shipping
}

\author{
Pierre Cariou * \\ François-Charles WOLFF **
}

$2012 / 47$

\section{Laboratoire d'Economie et de Management Nantes-Atlantique Université de Nantes \\ Chemin de la Censive du Tertre - BP 52231 \\ 44322 Nantes cedex 3 - France \\ www.univ-nantes.frliemn-iae/recherche}

Tél. +33 (0)2 40141717 - Fax +33 (0)2 40141749 


\title{
Chartering practices in liner shipping
}

\section{Pierre CARIOU}

Corresponding author. Euromed Management, Domaine de Luminy BP 921 - 13288

Marseille Cedex 9, France. Tel: 0033 (0)4 918278 59; Fax: 0033 (0)4 91827983

E-mail: pierre.cariou@euromed-management.com

\section{François-Charles WOLFF}

LEMNA, University of Nantes, France and INED, Paris, France.

E-mail: francois.wolff@univ-nantes.fr www.sc-eco.univ-nantes.fr/ fcwolff

\begin{abstract}
Chartering rather than owning a vessel is a recurrent question for liner operators. This article aims at identifying the extent of such chartering practices, the characteristics of vessels chartered and if an impact on liner profitability can be found. To do so, an initial dataset collected in 2009 on 510 liner operators and 5,005 vessels is used. Results from random effect Probit models point out first that chartering rates are not different between small and large operators. Furthermore, findings suggest that chartering of small and young vessels is more common and that chartering rates have increased for companies subject to higher fleet growth from 2007 to 2009. An analysis using a fixed effect Logit model on intra-fleet management of 17 selected liner companies further stresses that larger companies have chartered more small vessels during the last 2 years, a result that may be explain by the need to allocate the financing to new larger vessels. We then study whether the chartering rate and the size of these 17 liner companies have had an influence on their observed profitability in 2007, 2008 and 2009. Our results suggest that those variables impact profitability, but in variable ways over time.
\end{abstract}

Keywords: Liner shipping, chartering, profitability 


\section{Chartering practices in liner shipping}

\section{Introduction}

Asset management is a key component of the operational and commercial success of container shipping lines. Confronted with over-capacity resulting from the recent financial and economic crisis over the last two years, container lines have implemented many measures to restore their profitability. The most cited actions are: postponing or cancelling the delivery of vessels, scrapping or laying-up vessels and slow steaming services [1].

When considering this list of actions, it turns out that little attention has been devoted to chartering. Liner operators always own a certain number of vessels to meet the minimum requirements of their contract engagements, but they also charter extra tonnage to meet specific market requirements [2]. For the sake of illustration, out of the 4,916 containerships operated by the top-100 liner operators in June $2011,57.8 \%$ in number and $52.7 \%$ in capacity were chartered. These figures are fairly similar to those observed in March 2007 since the proportions were $57.1 \%$ and $51.8 \%$ respectively [3].

The extent of these charter practices and its potential impact on profitability of liner shipping companies is the topic under investigation in this paper. Our contribution is to shed light on these practices using a large dataset of the containership fleet. For a subsample of the largest operators, we also study the relationship between chartering practices and profitability.

To do so, our paper is organized as follows. The first section presents a literature review on asset management in liner shipping and provides some background information on chartering practices. In Section 3, we gather some descriptive statistics on the extent of this decision by liner operators in 2009. Section 4 provides an econometric analysis describing how vessel and firm characteristics influence chartering practices. We further study chartering strategies using a sub-sample of 17 large liner operators. Section 5 presents some preliminary estimations of the relationship between operating profit margins and chartering 
practices and size of these firms in 2007, 2008 and 2009. Finally, Section 6 provides concluding comments and outlooks for further research.

\section{Literature review}

There are many operational strategies to absorb over-capacity. According to Notteboom [1], lay-up and slow steaming/re-routing services have been the most effective in recent years [4-5]. These strategies combined with strategic alliances and mergers and acquisitions [6-8] contribute to restoring profitability in a proportion that is difficult to assess in markets that have recently subjected to large fluctuations in freight rates.

Fleet management in chartering instead of owning the vessel is another option largely used by the main operators. The proportion of chartered vessels was equal to $57.8 \%$ among the top-100 operators in June 2011 [3]. In 2010, 2,406 transactions were recorded: this number has substantially increased over the last few years since it was respectively 1,485 and 1,717 in 2008 and 2009 [8-10]. This increase in the number of transactions is a likely consequence of the financial crisis that has led most operators to charter-in vessels.

Compared to the owing of a vessel, chartering presents a number of advantages. Firstly, it reduces the debt leverage ratio [11]. Secondly, chartering offers the possibility of allocating resources to other activities such as door-to-door services [12]. Thirdly, it secures future slot costs that are pre-established within the charter party [13]. Fourthly, chartering provides an indirect access to ship funds, leasing or partnership structures [14]. Finally, it is a way for a company to benchmark its owned vessel operating performances with those of chartered vessels [15].

Most background information on chartering practices is found in the "grey" literature and can be summarized in the following way. Chartered container vessels are predominantly controlled by German interests with a specific partnership structure known as "Kommandit Gesellschaft" or KG funds which has existed since 1969 [11]. KGs are closed end funds, not limited to shipping, that provide tax concessions to investors. They combine the advantages of a partnership with those of a limited liability corporation. Initially implemented to 
stimulate investment in German flag registered ships, this agreement led the country to own approximatively $58 \%$ of all chartered containerships in 1998 [13]. While the tax advantages expected from KGs have since been considerably reduced, $15 \%$ of KG investments were still allocated to containerships in 2005, amounting to 10 billion Euros [14]. Today, German owners control around 35\% of all containerships (in teu) on the chartering market [16].

The vast majority of chartered vessels are mid-sized vessels: only 18 out of the 404 transactions recorded during the fourth-quarter of 2010 were more than 5,000 teu vessels, compared to 221 vessels that were less than 2,000 teu [10]. The mean charter durations and rates are subject to significant fluctuations. For a 4,000 teu vessel, the average duration was 24 months in 2007, but it was three times lower (8.1 months) for transactions recorded during the last trimester of 2010. Charter rate fluctuations are also paramount, moving from 26,100 USD per day in 2008 to 5,200 USD per day in 2009 for 4,000 teu vessels. Finally, some differences among the various vessel types are explained by changes in operating costs, which vary respectively according to size and age [17].

Companies' chartering practices are expected to impact their financial performance. The latter has been greatly affected during recent years, as highlighted by the case of Maersk Line (-1,938 USD Million in operating profits in 2009), CGA-CGM (-1,148 USD Million) and COSCON (-1,144 USD Million). Interestingly, to the best of our knowledge, there is no study to date that has attempted to investigate the relationship between chartering decisions and financial performance. The main difficulty is that the relationship between chartering practices and liner profitability is ambiguous on a priori grounds.

On the one hand, operators who were chartering significantly more with long duration contracts were probably in a worse situation when the crisis hit the liner shipping markets in mid-2008. Once the market collapsed, they were unable to quickly reduce their overcapacity. On the other hand, operators who were chartering more with short term duration contracts were able to reduce over-capacity and to take advantage of the recent decrease in chartering rates in 2009. 
Using data on a sub-sample of 17 large liner operators, this last issue will be subject to further investigation in the final section of this article. Meanwhile, we in the next section provide an econometric analysis of chartering practices in 2009.

\section{Chartering practices: data selection and identification}

Our empirical analysis is based on exhaustive data from Lloyd's Register Fairplay collected in 2009 [18]. This data set includes information on all merchant vessels in the world fleet. In what follows, we focus our attention on containerships. This leaves us with a sample comprising 4,220 vessels in 2007, 4,616 in 2008 and 5,005 vessels in 2009. For each vessel, information was retrieved on its owner and on its operator with the view that when the company's name is different, the vessel is chartered by the operator.

One difficulty when analysing the extent of chartering practices in liner shipping is that a prior identification of potential shareholding ties between legal proprietors and operators in charge of the commercial decisions on vessel deployment is required. Due to shipping practices where companies often finance the acquisition of vessels through subsidiaries, this identification is far from being straightforward.

On the basis of their names, we identified 890 different ship-owners and 580 different operators in our original data. However, these numbers undoubtedly over-estimate the exact numbers of owners and operators as they include subsidiaries. To limit this bias, we use owners' and operators' websites as well as professional publications (Alphaliner and Drewry publications) to reconstitute shareholding ties between operators and owners.

For the sake of illustration, vessels operated by Safmarine Container Lines, Moller AP, Moller-Maersk A/S, Mercosul Line, Ocean Africa Container Lines were all considered as part of the same operating group (renamed Maersk Line). At the owner level, Moller AP, Moller W, Nedlloyd Genoa Ltd, Nedlloyd Marseille Ltd, Maersk Line, Royal P\&O Nedlloyd NV were 
also considered as part of the Maersk Line's owner group. It follows that a vessel belonging to these two groups was not considered as chartered, but as a Maersk Line's vessel ${ }^{1}$.

Following this screening of our initial dataset, our sample was downsized to 760 owners and 510 operators. For 2,767 of the 5,005 vessels operated in 2009 (55.2\% of vessels), the name of the operator differs from the name of the owner. The proportion was equal to $57.6 \%$ in 2007 and $57.2 \%$ in 2008 respectively. It is interesting to note that these chartering rates are very similar to the proportion of $57.1 \%$ reported in March 2009 by Alphaliner for the top-100 liner operators [19].

For each vessel, we also gathered information from the LRF database on its age (in years) and size (in teu). We exploit this information to calculate a proxy for the chartering rate in the following way. We first use representative one-year time charter rates contracted in 2008 [20]. These rates were 5,000 USD/day for a 500 teu, 9,000 USD/day for a 1,000 teu, 15,000 USD/day for a 1,700 teu, 25,000 USD/day for a 2,500 teu and 35,000 USD/day for a 4,000 teu. As a rule of thumb, we decided to use a $10 \mathrm{USD} /$ day/teu rate for less than 1,000 teu vessels, and then reduced by 1 USD every 2,000 teu increase.

Keeping the same assumption $f$, the method leads to 4 USD/day/teu, or for a 14,000 teu vessel 56,000 USD/day ${ }^{2}$. The few figures reported by ship brokers in 2008 show that 13,10014,000 teu vessels are chartered at a rate of 58,700-60,650 USD/day, a value in line with our estimates. Then, a conservative assumption of a $3 \%$ increase in charter rates for every year of age was finally considered to account for the impact of age on operating costs [17].

Table 1 presents some descriptive statistics on vessels and operators in 2009. A first insight is the similarity in the rate of chartering between small (less than 5 vessels) and large (more than 100 vessels) operators, respectively $56.7 \%$ and $57.5 \%$. As expected, Germany is the first country of ownership in terms of number of vessels operated, with $13.8 \%$ of all vessels in number, equivalent to $17 \%$ of the 13.7 million teu world capacity.

\footnotetext{
${ }^{1}$ Similar groupings were done for all operators and owners. The coding is available upon request from the authors.

${ }^{2}$ For this category of vessels, a representative rate does not exist due to the limited number of transactions on the chartering market.
} 
A detailed analysis for chartered vessels stresses that $52 \%$ of the 2,767 vessels in number and $26 \%$ in teu capacity are controlled by owners registered in Germany - a result lower than the 35\% reported by Deutsche Bank Research for 2010 [16]. In 2009, Doehle owned 77 vessels on the chartering market, ER Shiffahrt GmBH (72 vessels), MPC (67), Hansa Shipping (61) and Buss $H(61)$. In the total rankings, the Chinese government with 75 vessels is the only non-German entity company within the top-5 chartering companies. Finally, vessels with higher chartering rates due to either their size and/or their age are, as expected, less chartered (43.6\%) than other vessels. They are however less frequent, representing $7 \%$ of all containerships.

Insert table 1 around here

To further identify differences in chartering practices among the largest operators, we chose to focus on a subset of 17 operators. These companies were selected because of the availability of information on their financial performances. These companies are Maersk Line, CMA-CGM, Hapag-Lloyd AG, APL Ltd, NYK, MOL, Hanjin, COSCON, OOCL, Evergreen, CSCL, CSAV, Hyundai, Yang Ming, Zim, Wan Hai and RCL. In 2009, they operated 2,382 vessels (corresponding to $47.6 \%$ of all vessels) equivalent to a carrying capacity of $8,697,831$ teu (63.5\% of the world teu capacity). The major liner operator missing from our sample is MSC. This company operates 393 vessels (it is ranked second after Maersk Line and before CMA-CGM), but it wasimpossible for us to retrieve any financial information. Figure 1 presents the number of owned and chartered vessels in 2009 within the 17 operators' respective fleets.

Insert figure 1 around here

The 17 companies have a mean chartering rate of $55.3 \%$, a proportion similar to the one observed earlier for the entire sample of 510 operators (55.2\%). Maersk Line is clearly ahead of all firms in terms of operated fleet, with about 500 vessels. The second operator in our sample is CMA-CGM (ranked third in the world), with about 300 vessels. There are large differences in the rate of chartering by operators. CSAV ( $98 \%$ of its operated fleet), Hyundai 
(83.6\%) and $\mathrm{MOL}(71.5 \%)$ charter much more on average, while the reverse pattern is found for RCL (15.9\%), COSCON (25.9\%) and Wan Hai (29.1\%).

There are also significant differences in the characteristics of vessels operated. As shown in table 2, companies like COSCON, Evergeen or RCL operate vessels of approximatively 11 years old on average. This is more than 5 years older than the mean age of vessels operated, for instance, by CSAV (5.9) or Hyundai (5.7). The largest fleet in size is operated by APL Ltd, Hanjin, OOCL and Hyundai with a mean size exceeding 4000 teu, while Wan Hai and RCL operate the smallest fleet.

Insert table 2 around here

Another interesting finding is that there are significant differences between the characteristics of chartered and owned vessels at the operator level. Consider for instance Maersk Line and CMA-CGM. On average, the vessels they own are much larger $(155 \%$ for Maersk Line, $180 \%$ for CMA-CGM) and slightly younger than the vessels they charter. Conversely, the mean size of chartered vessels is larger than that of owned vessels in the case of operators like COSCON, CSAV, or APL Ltd. The next section provides further insight by developing an econometric analysis applied to the entire sample and then to the 17 operators.

\section{Econometric analysis of chartering practices}

We turn to an econometric analysis to further study the role played by the characteristics of operators and vessels on chartering rates. Let $C_{j i}^{*}$ be a latent variable measuring the propensity that a company $j$ decides to charter a vessel $i$. We rely on the following linear expression for $C_{j i}^{*}$ :

$$
C_{j i}^{*}=X_{j} \beta+Z_{j i} \delta+u_{j}+\varepsilon_{j i}
$$


where $X_{j}$ and $Z_{j i}$ are sets of characteristics respectively specific to the operators and to the vessels, $\beta$ and $\delta$ are vectors of coefficients to estimate, and $u_{j}$ and $\varepsilon_{j i}$ are random perturbations. On the one hand, $u_{j}$ is an operator-specific unobserved heterogeneity term that will pick up preferences for chartering. On the other hand, $\varepsilon_{j i}$ is a pure random term specific to each vessel. We assume that both perturbations are normally distributed such that $u_{j} \sim N\left(0 ; \sigma_{u}^{2}\right)$ and $\varepsilon_{j i} \sim N(0 ; 1)$. By definition, $C_{j i}^{*}$ is unobserved, but we know that the decision to charter a vessel $C_{j i}$ is such that $C_{j i}=1$ when $C_{j i}^{*}>0$ and $C_{j i}=0$ when $C_{j i}^{*} \leq 0$. It thus follows that the probability of a vessel being chartered is:

$$
\operatorname{Pr}\left(C_{j i}=1\right)=\Phi\left(X_{j} \beta+Z_{j i} \delta+u_{j}\right)
$$

with $\Phi$ the cumulative distribution function of the univariate standard normal distribution. We note that the probability $\operatorname{Pr}\left(C_{j i}=1\right)$ depends on the unobserved operator component $u_{j}$. Let $\Gamma_{\mathrm{ji}}=X_{j} \beta+Z_{j i} \delta+u_{j}$. For a given operator, it follows that:

$$
\operatorname{Pr}\left(C_{j 1}, \ldots, C_{j I}\right)=\int_{-\infty}^{+\infty} \prod_{i=1}^{I}\left[\Phi\left(\Gamma_{\mathrm{ji}}\right)\right]^{C_{j i}}\left[1-\Phi\left(\Gamma_{\mathrm{ji}}\right)\right]^{1-C_{j i}} \phi\left(u_{j}\right) \mathrm{d}\left(u_{j}\right)
$$

with $\phi$ the density function of the multivariate normal distribution. This specification defines a random effect Probit model that is estimated using quadrature techniques [21]. The underlying assumption behind the random effect framework is that the operator-specific unobserved heterogeneity terms are uncorrelated with the characteristics of the vessels. The corresponding estimates, applied to the sample of 510 operators and 5,005 vessels, are presented in table 3.

Insert table 3 around here

As shown in column (1), at conventional levels, the size of the operator does not significantly influence the decision of chartering a vessel. In column (2), we introduced the growth rate in the fleet operated by an operator over the 2007-2009 period. As a reminder, the growth rate in the operated fleet over this period amounts to 18.6\%, from 4,220 vessels in 2007 to 5,005 in 2009. We find that this covariate is positively correlated with the rate of chartering. This 
suggests that operators that have increased their fleet have done so by slightly increasing the proportion of vessels chartered. An explanation of this result is that it is obviously easier and faster to charter than to buy.

According to table 3, chartering is less frequently observed for older vessels. The negative correlation between chartering and age of vessel is significant for vessels over 10 years old and is much higher for vessels over 20 years old. A similar pattern is found for vessel size. The probability of chartering is significantly lower for larger vessels than for 4,000 teu. Given the high correlation between vessel characteristics (age/size) and chartering rates, we only include the latter covariate in column (3). Finally, we find that vessels with high chartering costs are less likely to be chartered.

In table 4, we enrich the analysis on the impact yielded by operator size by providing some descriptive statistics on the fleet management strategy. Since the chartering decision is binary, this implies that a given operator may face the following three configurations: either all vessels are chartered, all vessels are owned, or some vessels are owned and some are chartered. The strategy is strongly affected by the size of an operator. The likelihood of having all vessels chartered strongly decreases with an operator's size, from $41.4 \%$ for companies with two vessels to $17.8 \%$ for companies with $11-50$ vessels. The proportion of companies with owned vessels also decreases with size, but essentially for operators with more than 5 vessels. Finally, the intermediate option or mixed strategy strongly increases with size: $33.3 \%$ for companies with $6-10$ vessels, $57.7 \%$ with $11-50$ vessels to reach $100 \%$ when an operator has a fleet of more than 100 vessels.

\section{Insert table 4 around here}

We then re-estimated the random effect Probit regressions for the sub-sample of 17 operators. Estimates in columns 1 and 3 of table 5 confirm earlier findings. We again observe the positive impact of a company's past two years growth on chartering rate, an effect higher than the earlier one $(+0.022$ against +0.003$)$. This result is not explained by the higher growth rates for these 17 companies, since the increase from 2007 to 2009 is equal to $14.1 \%$ versus $18.6 \%$ for the 510 operators. It mainly stems from the presence in our sample of 
companies that have a relative tendency to charter more often ${ }^{3}$. Finally, in line with our former findings, chartering for these companies is also less frequent when vessels are older, larger (above 6000 teu) or have higher chartering costs (column 3).

Insert table 5 around here

Since there are many vessels per operator in the data, we decided to further investigate how the characteristics of chartered vessels differ from those of the vessels he owns (column 2). To analyze the issue for the 17 selected operators, we estimated a fixed effect Logit model using a conditional likelihood maximization [22]. Since the characteristics of an operator are by definition the same for all the vessels of its fleet, they are picked up by a fixed effect and they are thus excluded from the list of covariates. The probability that a vessel is chartered within an operator's fleet can therefore only be a function of its age and size.

As shown in column 2, the fixed effect framework had little influence on our results. Estimates confirmed the existence of a negative correlation between the likelihood of chartering and both the age and size of the vessel. On average, operators own older and larger vessels while they charter-in younger and smaller vessels. This pattern is still observed when using the chartering cost proxy (column 4). This last result is interesting in light of the impressive growth in the number of large vessels during the period. For instance, the number of more than 6,000 teu vessels increased by $51 \%$ over the period to reach 478 vessels in 2009 compared to 317 in 2007, while less than 6,000 teu containerships grew by $16 \%$ in number.

\section{The impact of chartering practices on profitability}

In this last section, we attempt to measure to what extent the chartering practices identified earlier for the 17 selected operators may have impacted their financial performance in 2007, 2008 and 2009. Information from the companies' financial statements was retrieved from [10]. It included their operating profit margins and revenues used to determine an operating

\footnotetext{
${ }^{3}$ For instance, broker information reported in [10] stresses that during the last trimester of 2009, CMA-CGM (46 vessels), Maersk Line (38) and CSAV (24) were the most active companies on the chartering market, these three companies being amongst our 17 selected operators.
} 
profit margin to revenue ratio (OPM hereafter). These results only concern the container activity of such companies. Figure 2 provides some primary results on the changes in OPM in 2008 compared to 2007 and 2009 compared to 2008.

Insert figure 2 around here

Due to the financial crisis that severely hit the shipping markets in mid-2008, all firms experienced negative figures in their OPMs in 2008 compared to 2007. This is the result of collapsing markets in the last quarter of 2008 , when the average container revenues fell by $11 \%$ at the global level and in particular by more than $24 \%$ for the Europe/Far East trade [9]. It is therefore not surprising to find that the two Chinese companies in our sample, CSCL and COSCON, recorded the highest drop in 2008 with around a 30\% decrease in OPM. The high exposure of these two companies to Asian markets is an obvious reason. COSCON reported a drop of $30 \%$ in its average volume transported in 2008 compared to a $14 \%$ drop for Maersk Line.

When turning to results for 2009 compared to 2008, we observe that some operators experienced a faster recovery than others. This is the case for instance for $\mathrm{RCL}, \mathrm{Hyundai}$ and OOCL. Conversely, four companies still reported negative figures: Zim, NYK, MOL and CSAV. For Zim, this result is due to their fleet deployment with an average drop in freight rate estimated at $3 \%$ combined with more than a $30 \%$ decrease in volume [9]. For NYK and MOL, this is mainly explained by their exposure to Europe/Far East trade where average freight rates dropped by $50 \%$. Finally, for the Chilean based shipping company CSAV, this is related to the collapse of South American exports and the company's choice in 2008 to opt for long term chartered contracts.

In figure 3, we examined whether these observed differences in OPMs may be attributed to operators' chartering practices, although we are fully aware of the fact that this can only be seen as one factor among others. Furthermore, given the huge changes in the economic context over the 2007-2009 period which hampered the potential relationship, we chose to represent year-specific correlations. 
As illustrated in the case of CSAV, greater chartering using long term contracts may negatively impact profitability when markets suddenly plummet such as in 2009. At the same time, greater chartering using short term contracts can positively impact profitability as the operator's fleet can be quickly reduced in the event of over-capacity. Figure 3 illustrates the ambiguous role played by the chartering rate. We observed a negative relationship in 2007. Companies that were chartering less were relatively more profitable and showed a slight upturn to a positive relationship in 2009. During this period, as mentioned earlier, the average charter duration dropped from 24 months in 2007 to 4 months in 2009.

Insert figure 3 around here

To further investigate this relationship, we first estimate an OLS model of OPM as a function of the operator's size in number of vessels and of the operator's chartering rate. Operator size was used as a proxy of company exposure on the market, with the idea that larger companies share similar positioning in terms of fleet deployment. According to the results reported in panel A of table 6 , we find that operator size has no influence, leading to the conclusion that small and large companies have been similarly impacted.

A negative correlation is found between OPM and a company's chartering rate, but the corresponding coefficient is not significant in 2007 (at the $1 \%$ level). At the same time, one likely reason for such a weak relationship might be due to our sample size which remains limited since we consider only 17 operators. In such a context, the presence of outliers in the data is likely to distort the classical ordinary least square estimates and to lead to unreliable results [23].

Given the dispersion of the data confirmed in figure 3, we decided to rely on a linear regression estimator, robust to outliers, and to apply the MM-estimator described in [24]. This estimator is robust to both vertical outliers (observations with outlying values for the $y$ dimension), good leverage points (observations with outlying values in the space of covariates, but located close to the regression line) and bad leverage points (observations outlying in the space of covariates and located far from the regression line). For instance, 
Figure 3 suggests that in 2009 a company like Zim is a vertical outlier, RCL and CSAV are good leverage points, but COSCON or Wan Hai tend to be bad leverage points.

\section{Insert table 6 around here}

In Panel $\mathrm{B}$, the MM-estimates suggest that it is indeed important to take into account the influence of outliers. The operator's size now plays a role and the increase in its coefficient over time suggests that larger operators had a tendency to recover faster from the crisis. For the three years under consideration, the chartering rate of a company has a statistically significant role when understanding profitability, albeit only a small one. In 2007 and 2008, when for instance the typical 12 month chartering rates for a 3,500 teu vessel were 29,35026,450 USD/day [9], a $1 \%$ increase in chartering rate slightly reduced the OPM of companies by $-0.174 \%$ in 2007 and $-0.071 \%$ in 2008 respectively.

This confirms the negative relationship that was suggested in figure 3 for these two years. The situation is then reversed in 2009 , when chartering rates soared to 7,600 USD/day: operators that chartered more generated more profits $(+0.101 \%)$ during this period. Our results therefore show the difficulty in linking chartering practices and profitability due to the substantial fluctuation in chartering rates over the period.

\section{Conclusions}

This article is a preliminary attempt to shed light on the extent and similarity of chartering practices by liner operators and to explore their impact on profitability. Far from being complete, it raises many questions both to the quality of information used and the interpretations of the results.

On the first issue, the shipping world has always been an intricate industry where direct and indirect relationships, strategic alliances and partnerships co-exist. Our investigation attempts to clarify certain relationships by establishing some shareholding ties between owners and operators. Nevertheless, this still leaves many open questions as to when these two entities should be considered separately. 
To provide an example, when dealing with vessels operated by MSC and analyzing the case of 510 operators, we decided to consider that each time a vessel was owned by a single ship company, registered only with the name of the vessel as owner, this was indeed a subsidiary of MSC and not a chartered vessel. To what extent this reflects the true ownership is an issue that probably requires more in-depth analysis. Another issue is the limited size of our dataset since we only consider 17 operators. This constraint is due to the availability of financial results, which reduces the possibility of implementing a more comprehensive analysis on factors influencing profitability.

Interpretation of our results is also subject to caution. Our empirical analysis suggests that the relationship between chartering practices and profitability evolves over time as both the rates of chartering per vessel and the contract duration change over time. Furthermore, many factors were not considered in this article [25]. For instance, what is the ship-owner's nationality and does he have stakes in a shipyard? Is the company private or government owned? Does past performance influence a company's decision to charter in a given year?

Nevertheless, this article provides a preliminary framework to tackle these issues. Further investigation would for instance incorporate additional information on charter contract durations and on company market-positioning. 


\section{References}

[1] NOTTEBOOM T., 2012, Container Shipping, in Talley W., (eds), The Blackwell Companion to Maritime Economics. First Edition (Blackwell Publishing Ltd).

[2] GORTON L., HILLENIUS P., IHRE R., and SANDEVÄRN A., 2009, Shipbroking and chartering practice (Informa, London).

[3] ALPHALINER, 2011. Alphaliner Top 100. Accessed 6 June 2011 at http://www.alphaliner.com/top100/index.php.

[4] NOTTEBOOM T., and VERNIMMEN B., 2008, The effect of high fuel costs on liner service configuration in container shipping, Journal of Transport Geography 17(5), 325-337.

[5] CARIOU, P., 2011, Is slow steaming a sustainable means of reducing CO2 emissions from container shipping, Transportation Research Part D (16), 260-264.

[6] RYOO, D.K., and THANAPOULOU, H.A., 1999, Liner alliances in the globalisation era: a strategic tool for Asian container carriers, Maritime Policy and Management 26, 349-367.

[7] SLACK, B., Comtois C., and McCalla R.J., 2002, Strategic alliances in the container shipping industry: a global perspective, Maritime Policy and Management 29, 65-75.

[8] DREWRY RESEARCH, 2009, Container Forecaster 1Q09, Drewry Maritime Research, London.

[9] DREWRY RESEARCH, 2010, Container Forecaster 1Q10, Drewry Maritime Research, London.

[10] DREWRY RESEARCH, 2011, Container Forecaster 1Q11, Drewry Maritime Research, London.

[11] STOPFORD, M., 2009, Maritime Economics (Routledge, New York).

[12] FREMONT A., 2009, Empirical evidence for integration and disintegration of maritime shipping, port and logistics activities. OECD/ITF Joint transport Research Centre Round Table on Vertical Relations between Transport and Logistics Businesses, 5-6 February 2009, Paris, $33 \mathrm{p}$.

[13] DREWRY SHIPPING CONSULTANT, 1999, Containerships charter market: A positive course for the new millennium, Drewry Shipping Consultant Ltd, London.

[14] VON OLDERSHAUSEN C., 2005. German KG Financing, a well proven ship finance alternative: overview and future challenge. Fourth City of London Biennial Meeting, 6-7 December 2005.

[15] CARIOU P., and WOLFF F-C., 2011, Ship-owners' decisions to outsource vessel management. Transport Review, 31(6), 729-724.

[16] DEUTSCHE BANK RESEARCH, 2011, Container shipping: Successful turnaround. Accessed 7 June 2011 at http://www.dbresearch.de/PROD/DBR INTERNET ENPROD/PROD0000000000271589.pdf.

[17] HSH NORDBANK, 2008, Operating costs 2008. A study on the operating costs of German ships. $\quad$ Retrieved August 2010 at http://www.hsh- 
nordbank.com/media/pdf/kundenbereiche/schifffahrt/research/betriebskosten studie08/b etr kosten studie kurz engl.pdf?

[18] LLOYD'S REGISTER FAIRPLAY, 2009. IHS Fairplay World Shipping Encyclopaedia. Accessed 1 June 2009 at http://www.ihs.com/products/maritime-information/ships/worldshipping-encyclopedia.aspx?pu=1\&rd=ihsfairplay com.

[19] ALPHALINER, 2009. Alphaliner Weekly Newletter 2009 (9), p. 1.

[20] DREWRY SHIPPING CONSULTANTS, 2010, Shipping Insights. Monthly Analysis of the Shipping Markets. Drewry Publishing Ltd, June.

[21] BUTLER, L.S., and MOFFITT, R., 1982, A computationally efficient quadrature procedure for the one factor multinomial Probit model. Econometrica, 50, 761-764.

[22] Chamberlain, G., 1980, Analysis of covariance with qualitative data. Review of Economic Studies, 47, 225-238.

[23] Rousseeuw P.J., Leroy A.M., 1987, Robust Regression and Outlier Detection (New York, John Wiley \& Sons).

[24] Verardi V., Croux C., 2009, Robust regression in Stata. Stata Journal, 9, 439-453.

[25] Hoffmann J., Sanchez R.J., and Talley W.K., 2004, Determinants of Vessel Flag" in Shipping Economics: Research in Transportation Economics 12, 173-219. 
Figure 1. Number of owned and chartered vessels in 2009, for selected operators

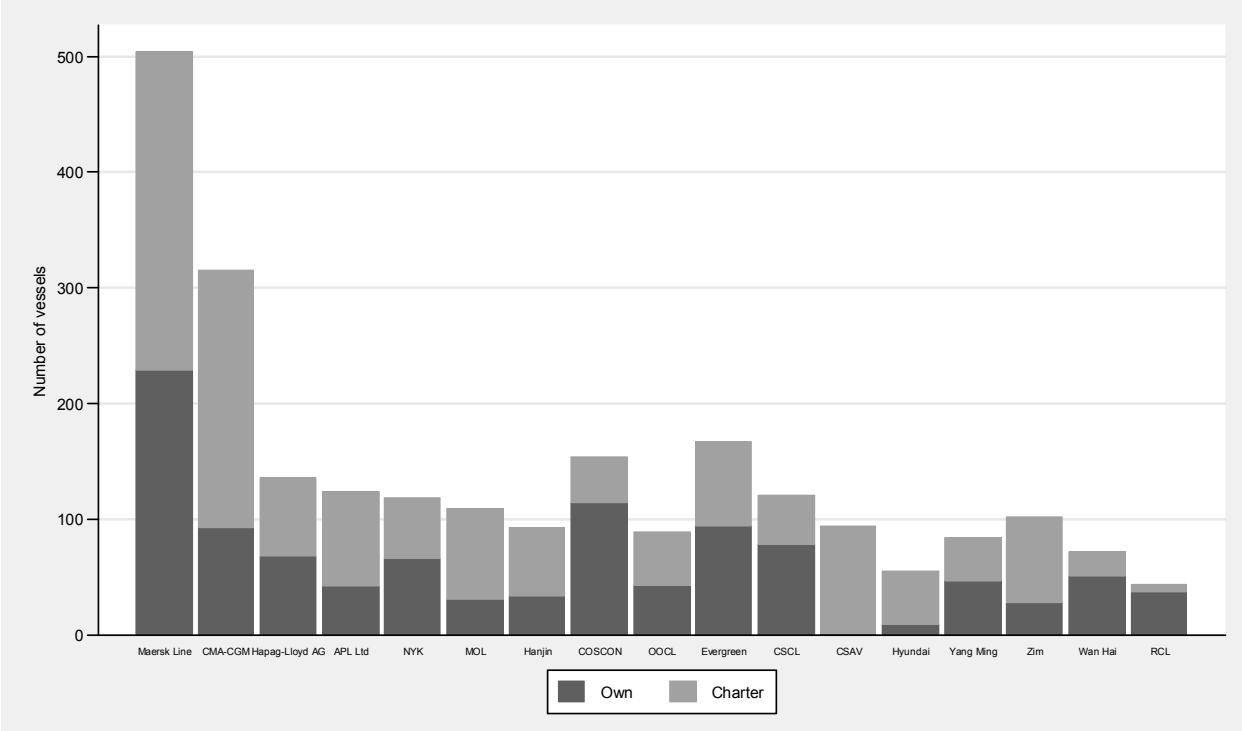

Source: Author's calculation from Lloyd's Register Fairplay - World Shipping Encyclopaedia (June 2009) 
Figure 2. Operating Profit Margin in 2008 and 2009, for selected operators

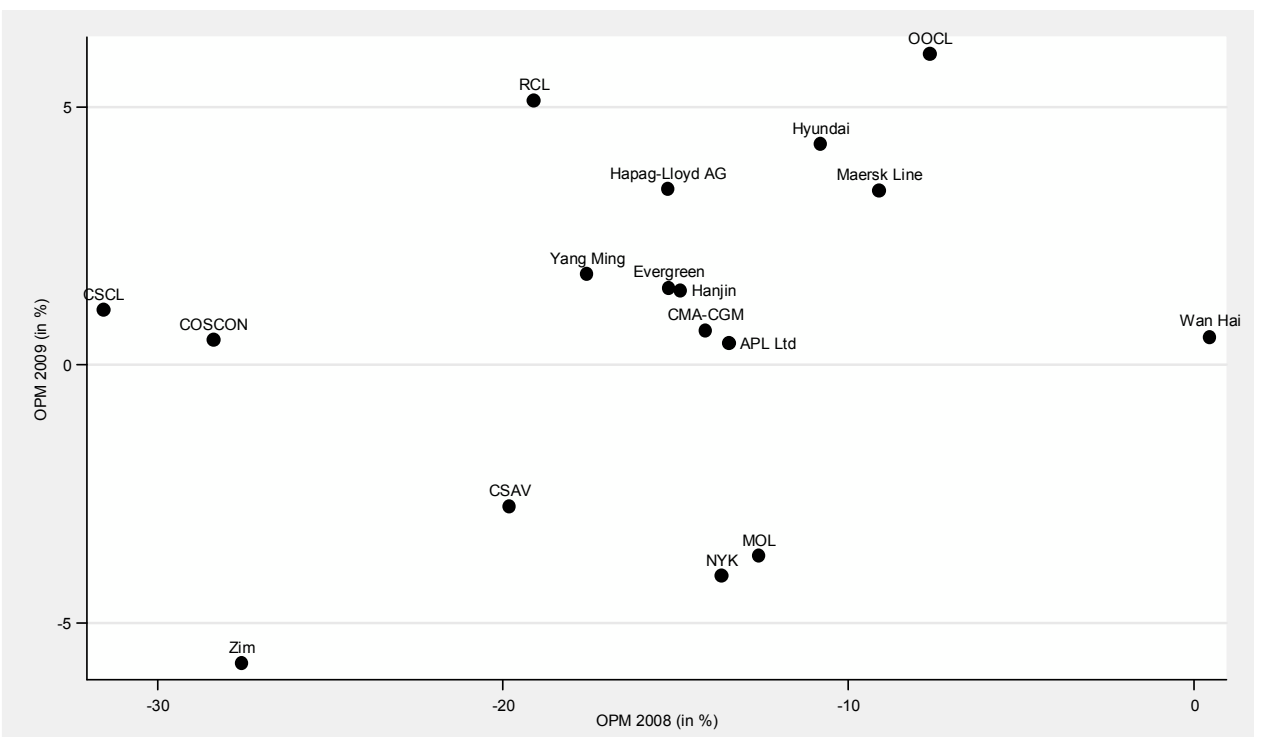

Source: Author's calculation from Lloyd's Register Fairplay - World Shipping Encyclopaedia (June 2009) and Drewry Research (2011) 
Figure 3. Chartering rates and operating profit margin A. 2007

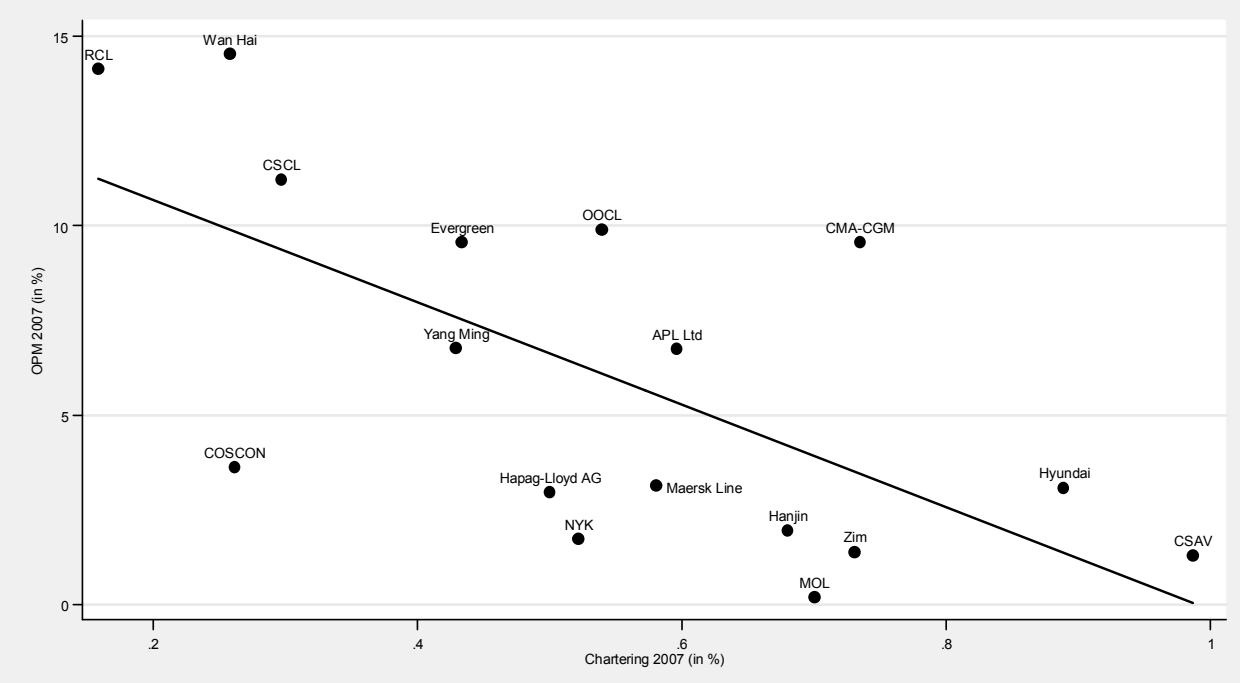

B. 2008

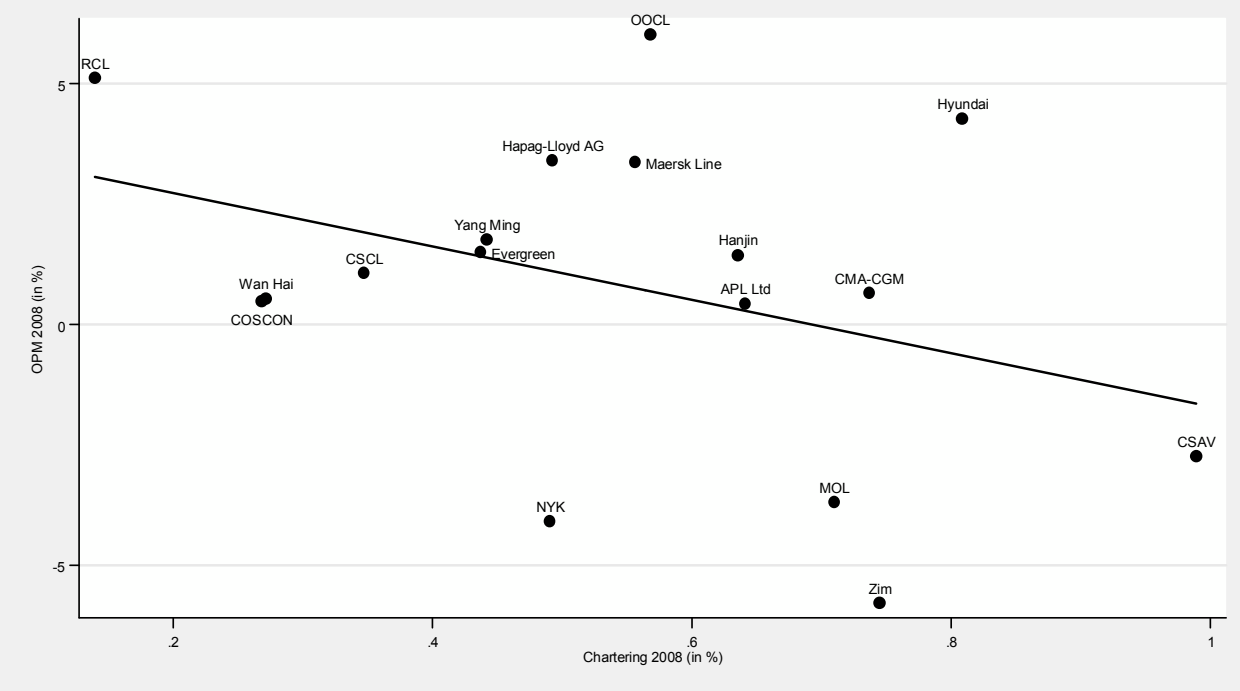

C. 2009

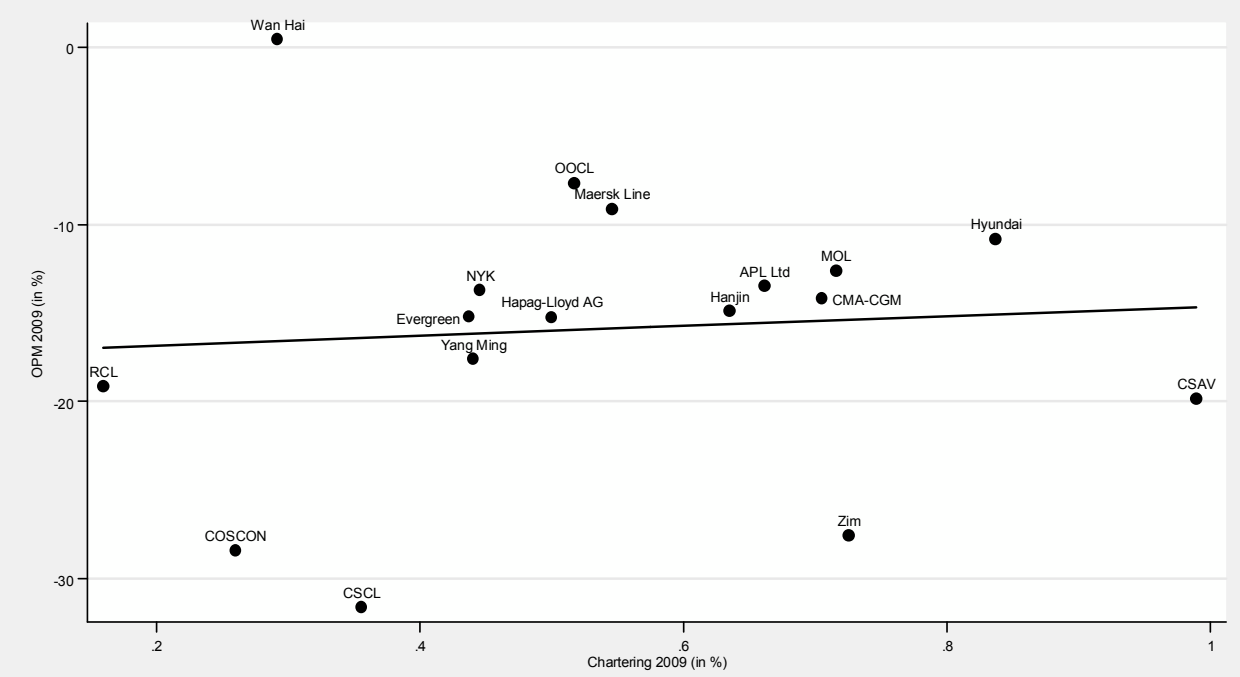

Source: Author's calculation from Lloyd's Register Fairplay - World Shipping Encyclopaedia (June 2009) and Drewry Research (2011) 
Table 1. Descriptive statistics of the sample for 2009

\begin{tabular}{llll}
\hline Variable (N=5,005 vessels) & Chartering rate (in \%) & $\begin{array}{l}\text { Distribution of vessels } \\
\text { (in \%) }\end{array}$ \\
\hline Operator's size & 0-4 vessels & 56.7 & 12.1 \\
& 5-9 vessels & 48.5 & 8.1 \\
& 10-49 vessels & 47.7 & 18.6 \\
& $50-99$ vessels & 62.0 & 9.7 \\
& $\geq 100$ vessels & 57.5 & 51.5 \\
Operator's nationality & Germany & 43.5 & 13.8 \\
& Denmark & 59.3 & 10.0 \\
& China & 46.5 & 7.9 \\
& Switzerland & 71.3 & 7.9 \\
& Japan & 60.0 & 7.2 \\
& Taiwan & 35.9 & 6.0 \\
& France & 69.6 & 5.9 \\
& Korea (South) & 60.6 & 5.1 \\
& Singapore & 40.2 & 4.7 \\
& USA & 67.0 & 4.4 \\
Total & Others & 57.3 & 27.2 \\
\hline in USD/year & $<10,000$ & 54.4 & 41.5 \\
& 10,000 - 19,999 & 59.6 & 23.8 \\
& 20,000 - 29,999 & 58.7 & 14.3 \\
& 30,000 - 39,999 & 52.7 & 13.4 \\
& $\geq 40,000$ & 43.6 & 7.0 \\
\hline
\end{tabular}

Source: Author's calculation from Lloyd's Register Fairplay - World Shipping Encyclopaedia (June 2009) 
Table 2. Descriptive statistics of the sample, for selected operators in 2009

\begin{tabular}{llllllll}
\hline Operator & \multicolumn{2}{l}{ Chartered vessels } & \multicolumn{2}{l}{ Owned vessels } & All & \multicolumn{2}{l}{ Vessels } \\
\cline { 2 - 7 } & Age & Size & Age & Size & Age & Size & Number \\
\hline Maersk Line & 8.5 & 3047 & 7.7 & 4721 & 8.2 & 3808 & 504 \\
CMA-CGM & 7.8 & 2809 & 7.1 & 5061 & 7.6 & 3474 & 315 \\
Hapag-Lloyd AG & 7.2 & 3351 & 13.7 & 4194 & 10.4 & 3773 & 136 \\
APL Ltd & 6.3 & 4251 & 14.5 & 3666 & 9.1 & 4053 & 124 \\
NYK & 9.3 & 2371 & 8.1 & 4773 & 8.6 & 3703 & 119 \\
MOL & 7.5 & 3435 & 10.4 & 4358 & 8.3 & 3697 & 109 \\
Hanjin & 7.8 & 3910 & 7.3 & 4630 & 7.6 & 4173 & 93 \\
COSCON & 6.0 & 4957 & 12.9 & 3178 & 11.1 & 3640 & 154 \\
OOCL & 6.8 & 3344 & 7.8 & 5669 & 7.3 & 4467 & 89 \\
Evergreen & 11.4 & 3729 & 11.1 & 3652 & 11.3 & 3686 & 167 \\
CSCL & 4.4 & 3863 & 10.5 & 3661 & 8.3 & 3733 & 121 \\
CSAV & 5.9 & 3231 & 10.0 & 1620 & 5.9 & 3214 & 94 \\
Hyundai & 6.3 & 5019 & 2.7 & 5516 & 5.7 & 5101 & 55 \\
Yang Ming & 7.3 & 3365 & 6.2 & 4201 & 6.7 & 3833 & 84 \\
Zim & 9.4 & 2679 & 11.5 & 3970 & 10.0 & 3033 & 102 \\
Wan Hai & 7.6 & 2009 & 11.2 & 1886 & 10.2 & 1922 & 72 \\
RCL & 14.3 & 1668 & 10.4 & 1293 & 11.0 & 1353 & 44 \\
\hline All (mean) & 7.8 & 3311 & 9.7 & 3651 & 8.7 & 3652 & 223 \\
\hline
\end{tabular}

Source: Author's calculation from Lloyd's Register Fairplay - World Shipping Encyclopaedia (June 2009) 
Table 3. Random effect Probit estimates of chartering in 2009

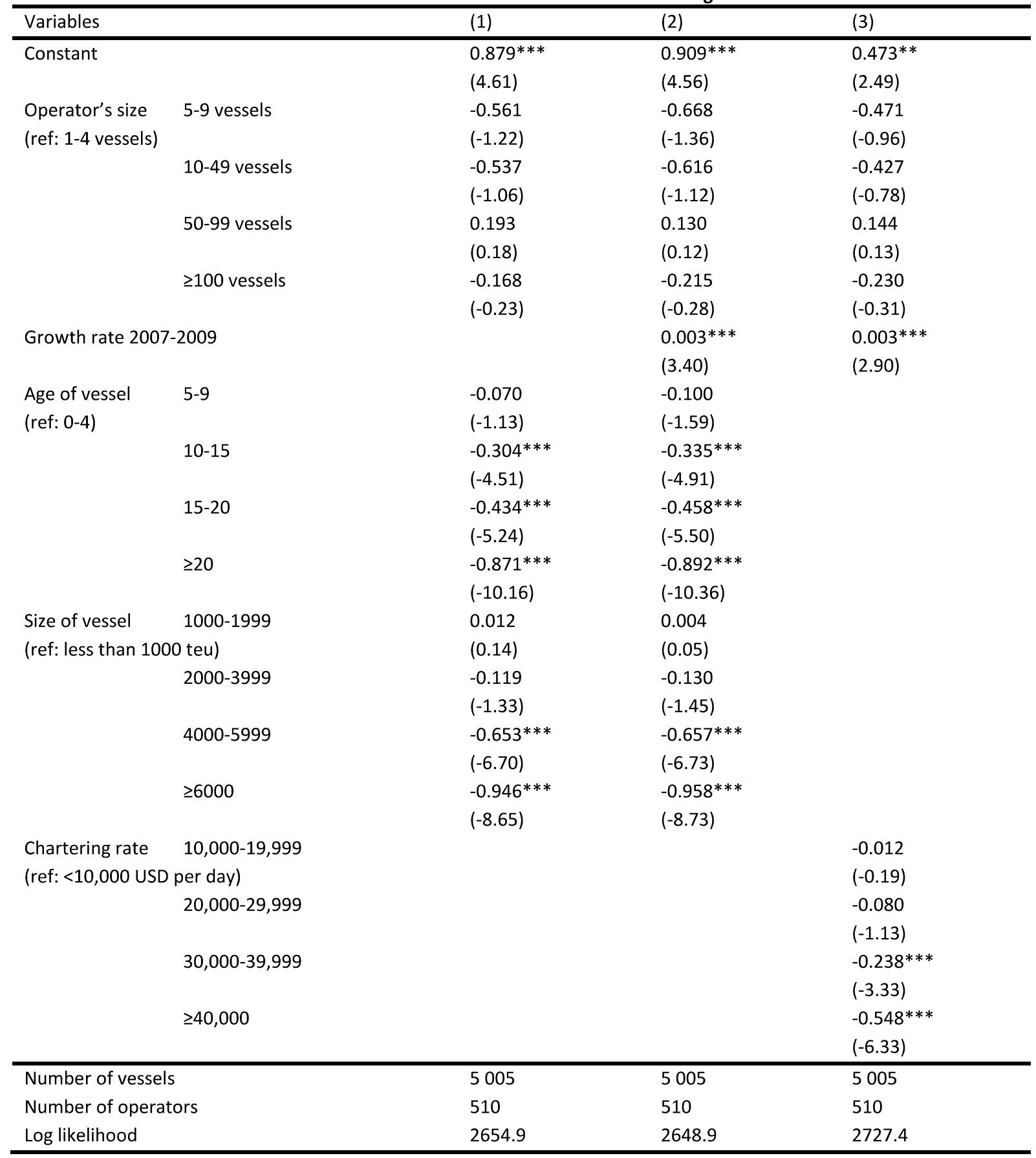

Source: Author's calculation from Lloyd's Register Fairplay - World Shipping Encyclopaedia (June 2009)

Note: estimates from random effect Probit models. Significance levels are respectively $1 \%\left({ }^{* * *}\right), 5 \%\left({ }^{* *}\right), 10 \%(*)$. 
Table 4. Fleet chartering decisions in \%, by operator size in 2009

\begin{tabular}{lccccccc}
\hline Operator's size in number of vessels & 1 & 2 & $3-5$ & $6-10$ & $11-50$ & $>50$ & $\geq 2$ \\
\hline All vessels chartered & 44.8 & 41.4 & 35.0 & 27.8 & 17.8 & 0 & 29.7 \\
Mix & 0 & 8.6 & 12.5 & 33.3 & 57.8 & 100 & 29.7 \\
None of vessels chartered & 55.2 & 50.0 & 52.5 & 38.9 & 24.4 & 0 & 40.5 \\
\hline Number of operators & 241 & 70 & 80 & 54 & 45 & 20 & 269 \\
\hline
\end{tabular}

Source: Author's calculation from Lloyd's Register Fairplay - World Shipping Encyclopaedia (June 2009) 
Table 5. Random and fixed effects estimates of chartering in 2009 , for selected operators

\begin{tabular}{|c|c|c|c|c|c|}
\hline \multicolumn{2}{|l|}{ Variables } & (1) & (2) & (4) & (5) \\
\hline \multirow{2}{*}{\multicolumn{2}{|c|}{ Constant }} & $0.585^{*}$ & & 0.242 & \\
\hline & & $(1.93)$ & & $(0.80)$ & \\
\hline \multirow{2}{*}{\multicolumn{2}{|c|}{ Number of vessels }} & 0.001 & & 0.001 & \\
\hline & & $(0.29)$ & & $(0.13)$ & \\
\hline \multirow{2}{*}{\multicolumn{2}{|c|}{ Growth rate $2007-2009$}} & $0.022 * * *$ & & 0.004 & \\
\hline & & (3.23) & & $(0.65)$ & \\
\hline \multirow{8}{*}{$\begin{array}{l}\text { Age of vessel } \\
\text { (ref: } 0-4)\end{array}$} & $5-9$ & $-0.245 * * *$ & $-0.306 * *$ & & \\
\hline & & $(-3.16)$ & $(-2.44)$ & & \\
\hline & $10-15$ & $-0.612 * * *$ & $-0.908 * * *$ & & \\
\hline & & $(-7.08)$ & $(-6.50)$ & & \\
\hline & $15-20$ & $-0.691 * * *$ & $-1.026^{* * *}$ & & \\
\hline & & $(-6.52)$ & $(-5.94)$ & & \\
\hline & $\geq 20$ & $-1.128 * * *$ & $-1.770 * * *$ & & \\
\hline & & $(-9.72)$ & $(-9.18)$ & & \\
\hline \multirow{8}{*}{$\begin{array}{l}\text { Size of vessel } \\
\text { (ref: less than } 1\end{array}$} & 1000-1999 & -0.059 & -0.113 & & \\
\hline & 0 teu) & $(-0.49)$ & $(-0.57)$ & & \\
\hline & 2000-3999 & -0.169 & -0.326 & & \\
\hline & & $(-1.41)$ & $(-1.64)$ & & \\
\hline & $4000-5999$ & $-0.763 * * *$ & $-1.291 * * *$ & & \\
\hline & & $(-6.18)$ & $(-6.30)$ & & \\
\hline & $\geq 6000$ & $-1.112^{* * *}$ & $-1.891 * * *$ & & \\
\hline & & $(-8.21)$ & $(-8.34)$ & & \\
\hline \multirow{2}{*}{\multicolumn{2}{|c|}{$\begin{array}{l}\text { Chartering cost } 10,000-19,999 \\
\text { (ref: }<10,000 \text { USD per day) }\end{array}$}} & & & -0.082 & -0.152 \\
\hline & & & & $(-1.01)$ & $(-1.14)$ \\
\hline \multirow{2}{*}{\multicolumn{2}{|c|}{$20,000-29,999$}} & & & -0.108 & -0.221 \\
\hline & & & & $(-1.23)$ & $(-1.54)$ \\
\hline \multirow{2}{*}{\multicolumn{2}{|c|}{$30,000-39,999$}} & & & $-0.312 * * *$ & $-0.535^{* * *}$ \\
\hline & & & & $(-3.65)$ & $(-3.86)$ \\
\hline \multirow{2}{*}{\multicolumn{2}{|c|}{$\geq 40,000$}} & & & $-0.575^{* * *}$ & $-1.012 * * *$ \\
\hline & & & & $(-5.50)$ & $(-5.95)$ \\
\hline \multicolumn{2}{|c|}{ Random effects - fixed effects } & RANDOM & FIXED & RANDOM & FIXED \\
\hline \multicolumn{2}{|c|}{ Number of vessels } & 2382 & 2382 & 2382 & 2382 \\
\hline \multicolumn{2}{|c|}{ Number of operators } & 17 & 17 & 17 & 17 \\
\hline \multicolumn{2}{|l|}{ Log likelihood } & -1405.6 & -1330.5 & -1488 & -1408.9 \\
\hline
\end{tabular}

Source: Author's calculation from Lloyd's Register Fairplay - World Shipping Encyclopaedia (June 2009)

Note: estimates from random effect Probit and fixed effect conditional Logit models. Significance levels are respectively $1 \%$ $\left({ }^{* *}\right), 5 \%\left({ }^{* *}\right), 10 \%\left({ }^{*}\right)$. 
Table 6. Estimates of the operating profit margin

A. OLS models

\begin{tabular}{llll}
\hline Variables & 2007 & 2008 & 2009 \\
\hline Constant & $13.649^{* * *}$ & 3.393 & $-18.447^{* * *}$ \\
& $(5.18)$ & $(1.46)$ & $(-3.05)$ \\
Operator's size & -0.003 & 0.004 & 0.008 \\
& $(-0.27)$ & $(0.52)$ & $(0.45)$ \\
Chartering rate (in \%) & $-0.134^{* * *}$ & -0.057 & 0.025 \\
& $(-3.26)$ & $(-1.53)$ & $(0.26)$ \\
\hline Number of operators & 17 & 17 & 17 \\
$\mathrm{R}^{2}$ & 0.436 & 0.152 & 0.020 \\
\hline & B. Robust regressions & & 2009 \\
\hline Variables & 2007 & 2008 & $-21.400^{* * *}$ \\
\hline Constant & $16.830^{* * *}$ & $3.407^{*}$ & $(-13.35)$ \\
& $(8.71)$ & $(1.78)$ & $0.011^{*}$ \\
Operator's size & $-0.009^{* * *}$ & $0.008^{* *}$ & $(1.89)$ \\
& $(-3.10)$ & $(2.44)$ & $0.101^{* * *}$ \\
Chartering rate (in \%) & $-0.174^{* * *}$ & $-0.071^{* *}$ & $(3.94)$ \\
\hline Number of operators & $(-5.10)$ & $(-2.74)$ & 17 \\
\hline
\end{tabular}

Source: Author's calculation from Lloyd's Register Fairplay - World Shipping Encyclopaedia (June 2009) and Drewry Research (2011)

Note: Significance levels are respectively $1 \%(* * *), 5 \%\left({ }^{* *}\right), 10 \%\left({ }^{*}\right)$. 